\title{
Riñón ectópico. Imágenes de la urografía intravenosa
}

\author{
Cerqueira Alves M, Brás Silva C, Ribeiro dos Santos A.
}

Servicio de Urología. Hospital de San Marcos. Braga. Portugal.

\section{Actas Urol Esp. 2008;32(3):370}

$\mathrm{P}_{\mathrm{y}}^{\mathrm{s}}$ aciente de sexo femenino, con 29 años de edad y sin antecedentes patológicos de interés que acudió a su médico asistente por quejas de dolor cólico a nivel del flanco derecho, que aumentaba en posición supina, aliviando en decúbito dorsal. El estudio realizado incluyó una urografía intravenosa, que mostraba la presencia de un riñón derecho ectópico, y que en posición de decúbito dorsal presenta una posición normal. Mientras que en posición supina adquiere una localización pélvica. A pesar de esta movilidad renal se verifica una normal eliminación del contraste en los dos riñones, sin presencia de dilatación pielocalicial ni imágenes sugerentes de obstrucción ureteral. La paciente fue sometida a nefropexia derecha, estando de momento asintomática.

Correspondencia autor: Dr. C. Brás Silva

Servicio de Urología. Hospital de San Marcos. Braga (Portugal) E-mail autor: brassilva@gmail.com

Información artículo: Imágenes en Urología

Trabajo recibido: octubre 2006

Trabajo aceptado: noviembre 2006

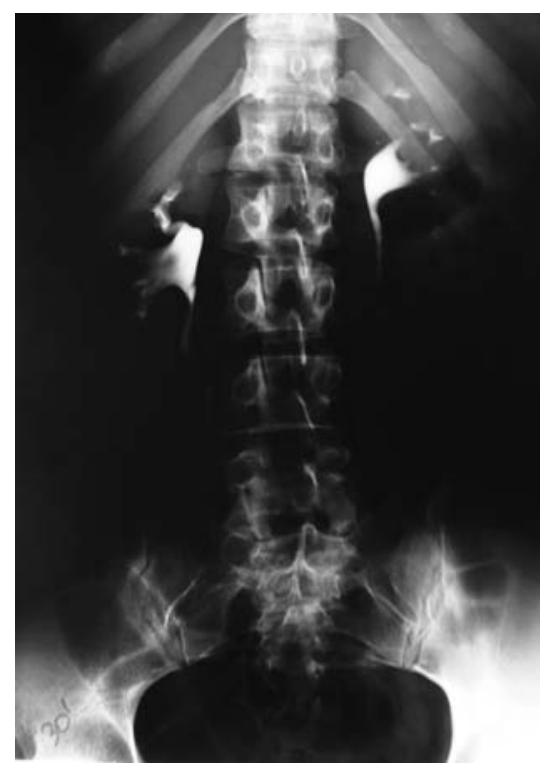

FIGURA 1

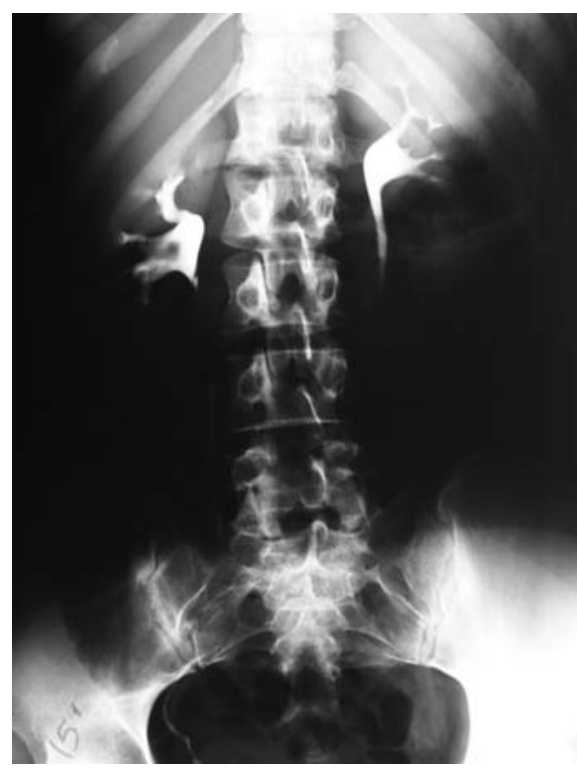

FIGURA 2

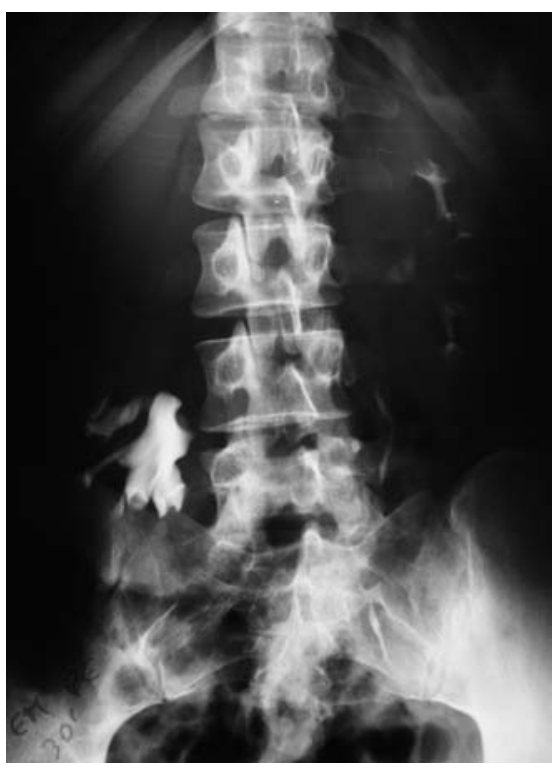

FIGURA 3 